\title{
Impact of phosphoinositide-3-kinase and vitamin D3 nuclear receptor single-nucleotide polymorphisms on the outcome of malignant melanoma patients
}

\author{
Francesca Morgese ${ }^{1}$, Davide Soldato ${ }^{1}$, Silvia Pagliaretta ${ }^{1}$, Riccardo Giampieri $^{1}$, \\ Donatella Brancorsini ${ }^{2}$, Mariangela Torniai ${ }^{1}$, Silvia Rinaldi ${ }^{1}$, Agnese Savini ${ }^{1}$, \\ Azzurra Onofri ${ }^{1}$, Marina Scarpelli ${ }^{2}$ and Rossana Berardi ${ }^{1}$ \\ ${ }^{1}$ Clinica Oncologica, Università Politecnica delle Marche, Azienda Ospedaliero-Universitaria Ospedali Riuniti "Umberto I-G.M. \\ Lancisi-G. Salesi", Ancona, Italy \\ ${ }^{2}$ Section of Pathological Anatomy and Histopathology, Deparment of Neuroscience, Università Politecnica delle Marche, \\ Azienda Ospedaliero-Universitaria Ospedali Riuniti "Umberto Iº-G.M. Lancisi-G. Salesi", Ancona, Italy \\ Correspondence to: Rossana Berardi, email: r.berardi@univpm.it \\ Keywords: PI3K SNPS, VDR SNPS, allele frequency, survival, melanoma \\ Received: April 13, $2017 \quad$ Accepted: April 27, $2017 \quad$ Published: May 30, 2017 \\ Copyright: Morgese et al. This is an open-access article distributed under the terms of the Creative Commons Attribution License 3.0 \\ (CC BY 3.0), which permits unrestricted use, distribution, and reproduction in any medium, provided the original author and source \\ are credited.
}

\section{ABSTRACT}

Background: Several studies associating single nucleotide polymorphisms (SNPs) frequencies with tumors outcome have been conducted, nevertheless malignant melanoma literature data are inconclusive.

Therefore we evaluate the impact of different genotypes for phosphoinositide3-kinase (PI3K) and vitamin D3 nuclear receptor (VDR) SNPs on melanoma patients' outcome.

Materials and methods: Genomic DNA of 88 patients was extracted from blood and tumor samples. SNPs were determined by PCR using TaqMan assays. We selected polymorphisms of the regulatory and catalytic subunit of PI3K (PIK3R1 and PIK3CA genes, respectively), analyzing rs2699887C $>$ T of PIK3CA and rs3730089G $>A$ of PIK3R1 SNPs. Furthermore we considered the following VDR SNPs: rs2228570A>G (Fok1), rs731236A > G (Taq1) and rs1544410C >T (Bsm1).

Progression free survival (PFS) and overall survival (OS) were estimated with the Kaplan-Meier method and with Mantel-Haenszel log-rank test.

Results: The statistical analysis for Fok1 of VDR showed a significant difference in PFS after the first line therapy (median PFS= $\mathbf{2 1 . 2}$ months in the homozygous recessive genotype group vs. 3.3 months of homozygous dominant and heterozygous ones, $p=0.03$ ). In particular, in homozygous recessive patients for Fok1 SNPs of VDR a high rate of histological regression and BRAF (B- Rapidly Accelerated Fibrosarcoma gene) mutation were observed. Furthermore, more efficacy of BRAF + /- MEK (MAPKERK-Kinase) inhibitors therapies in homozygous recessive patients vs. homozygous dominant and heterozygous ones was shown.

Conclusions: Our study showed a significant correlation between homozygous recessive genotype of Fok1 SNPs of VDR gene and an increased PFS in patients who underwent a first line therapy with BRAF inhibitors.

\section{INTRODUCTION}

Malignant melanoma is the most aggressive skin cancer and the fifth and seventh most common cancer in developed countries among men and women, respectively. By the end of 2016 it is estimated that 76,380 malignant melanoma of the skin will be diagnosed and 10,130 diseaserelated deaths will occur, in the United States only [1]. 
The 5-year probability of surviving malignant melanoma ranges from $98 \%$ to $<20 \%$ [2] depending on the stage of disease at diagnosis [3].

Evidences suggest that sex, age at presentation, histological features and stage of disease at time of diagnosis represent important factors influencing melanoma progression and survival [4-15].

Recently, important biological mechanisms have been examined for their contribution to the development and progression of malignant melanoma, including the phosphatidylinositol 3-kinase (PI3K)/PTEN/AKT/mTOR signaling pathway and the nuclear vitamin $\mathrm{D}$ receptor (VDR) function.

Many growth factors and cytokines are responsible for the activation of these two pathways implicating cell growth and death $[16,17]$.

In particular, numerous and different human tumors exhibited genetic alterations in the PI3K pathway. Specifically, PIK3CA, which encodes for the catalytic subunit $\mathrm{p} 110 \alpha$ of class IA PI3-kinase, is amplified and overexpressed in ovarian cancer [18] and is commonly gain-of-function mutations in colon [19], brain [20], breast [21] and gastric cancers [22-25], but PIK3CA mutations seem to have a limited impact on growth of melanoma, up to now [26].

On the other side PIK3R1, encoding for the regulatory subunit p85 of PI3K, shows mutations especially in ovarian, colon [27], endometrial [28], prostate cancer [29], glioblastoma [30] and also in malignant melanoma [31].

Finally, considering VDR, its higher expression has been related to better survival in patients with lung [32, $33]$ and breast cancer [34, 35].

A lower VDR expression, at the same time, was observed in melanoma especially for the vertical growth phase versus normal skin or nevi [36] and hypo-activation of VDR signaling pathway can inhibit melanocytic progression [37].

Frequent epigenetic and genetic alterations, such as single-nucleotide polymorphisms (SNPs), may increase or decrease the function of genes in VDR signaling pathways, resulting in susceptibility and modified prognosis of malignant melanoma [38-40].

Some variants of PIK3CA and PIK3RI SNPs were studied in different type of tumor demonstrating an influence on prognosis [41-47] but in malignant melanoma, PI3K polymorphisms have not been evaluated yet.

For more common variants of polymorphisms in the VDR gene, available data indicated their capacity to change disease-specific survival in patients with breast cancer [48], lung cancer [49, 50] ovarian cancer [51] colorectal cancer [52, 53], renal cell carcinoma [54], prostate tumor [55-57], head and neck squamous cell carcinoma $[58,59]$, glioma [60] and, only very recently, in patients with malignant melanoma [46].

Currently, the treatment of advanced malignant melanoma made use of immuno-therapy with PD-1 and CTLA-4 inhibitors and, for melanomas harboring BRAF mutation, also, of target therapy with BRAF and MEK inhibitors.

Our study aimed to examine the associations between the clinical outcomes of malignant melanoma and some variants of SNPs in PIK3CA, PIK3R1 and VDR genes.

\section{RESULTS}

We enrolled 88 consecutive patients treated for cutaneous or occult malignant melanoma between 2012 and 2016: 48 with no evidence of disease (NED) and 40 with metastatic melanoma. Genotypes characteristics of the studied population are summarized in Table 1.

We did not observe a statistically significant difference in frequency distribution of polymorphisms between NED patients and metastatic ones.

The MAF (minor allele frequency) for all studied SNPs was $>10 \%$, therefore most statistical analysis were conducted applying a dominant model: patients with homozygous dominant and heterozygous genotype were compared with those with homozygous recessive ones.

In the pooled population, homozygous recessive genotype was not detected for SNP rs1544410 (Bsm1) of $V D R$ while for SNP rs3730089 of PIK3R1 the number of homozygous recessive patients was too small to obtain statistical results, therefore we compared homozygous dominant with heterozygous patients.

All the examined polymorphisms fit the HardyWeinberg equilibrium (HWE), except for Bsm1 SNP of VDR gene.

Therefore we did not include data about Bsm1.

In terms of OS, we observed no statistical differences between the two groups of patients evaluated for the SNPs rs3730089 in the PIK3R1 gene and VDR SNPs rs2228570 (Fok1), rs731236 (Taq1).

Nevertheless, for the SNP rs2699887 of PIK3CA gene, a very interesting trend of better OS in dominant homozygous and heterozygous genotype vs. recessive homozygous one was shown (median OS= 185.1 months vs. 19.4 months, respectively with a hazard ratio $(\mathrm{HR})=$ 0.28 (95\% CI: 0.02-3.61), $p=0.06$ ) (Figure 1).

Furthermore, in the cohort of metastatic patients we identified no statistical differences, in terms of PFS, between the selected groups for SNPs rs2699887 in the PIK3CA gene, rs3730089 in the PIK3R1 gene and Taq1 in the VDR gene.

Considering the SNP Fok1, we observed statistical differences in PFS after the first line of treatment in favor of homozygous recessive patients vs. homozygous dominant and heterozygous ones (median $\mathrm{PFS}=21.2$ months vs. 3.3 months, respectively with $\mathrm{HR}=0.26(95 \%$ CI: 0.09-0.69), $p=0.03$ (Figure 2).

In particular, we observed that the homozygous recessive genotype in the Fok1 polymorphism is associated with a higher rate of tumor histological 
Table 1: distribution of polymorphism genotypes among NED and metastatic patients

\begin{tabular}{|c|c|c|c|c|c|}
\hline Gene & Polymorphism & Patients'group ${ }^{a}$ & Patients in NED & Metastatic patients & Unknown \\
\hline & & $\mathrm{HD}$ & $34(38.6 \%)$ & $24(27.2 \%)$ & \\
\hline \multirow[t]{3}{*}{ PIK3CA } & rs2699887 & $\mathrm{Ht}$ & $11(12.5 \%)$ & $13(14.8 \%)$ & $2(2.3 \%)$ \\
\hline & & HR & $2(2.3 \%)$ & $2(2.3 \%)$ & \\
\hline & & HD & $38(43.2 \%)$ & $33(37.5 \%)$ & \\
\hline \multirow[t]{6}{*}{ PIK3R1 } & rs3730089 & $\mathrm{Ht}$ & $8(9.1 \%)$ & $6(6.8 \%)$ & $1(1.1 \%)$ \\
\hline & & HR & $2(2.3 \%)$ & 0 & \\
\hline & & HD & $22(25.0 \%)$ & $17(19.3 \%)$ & \\
\hline & rs 2228570 & $\mathrm{Ht}$ & $20(22.7 \%)$ & $16(18.2 \%)$ & $2(2.3 \%)$ \\
\hline & & $\mathrm{HR}$ & $6(6.8 \%)$ & $5(5.7 \%)$ & \\
\hline & & HD & $16(18.2 \%)$ & $17(19.3 \%)$ & \\
\hline \multirow[t]{5}{*}{$V D R$} & rs 731236 & $\mathrm{Ht}$ & $21(23.9 \%)$ & $15(17.0 \%)$ & $4(4.5 \%)$ \\
\hline & & HR & $8(9.1 \%)$ & $7(8.0 \%)$ & \\
\hline & & $\mathrm{HD}$ & $18(20.4 \%)$ & $17(19.3 \%)$ & \\
\hline & rs 1544410 & $\mathrm{Ht}$ & $29(33.0 \%)$ & $22(25.0 \%)$ & $2(2.3 \%)$ \\
\hline & & HR & 0 & 0 & \\
\hline
\end{tabular}

${ }^{a} \mathrm{HD}, \mathrm{Ht}$ and HR stand respectively for: homozygous dominant, heterozygous and homozygous recessive.

regression $(28 \%$ vs $8 \%$ in homozygous dominant and heterozygous patients; $p=0.05$ ) and a higher incidence of BRAF mutations $(100 \%$ vs $36 \%$ in homozygous dominant and heterozygous patients; $p=0.01$ ) in the primary melanoma. Among the metastatic patients, 17 of $40(42.5 \%)$ resulted in melanomas harboring BRAF mutation, and 12 of them $(70.6 \%)$, received BRAF +/- MEK inhibitors as first line of treatment; the treatment of the remaining patients is shown in Table 2. Furthermore, patients carrying a homozygous recessive genotype (41.7\%) in the Fok 1 polymorphism showed a better disease control rate by the first line of treatment with anti-BRAF $+/$ - anti-MEK drugs vs. homozygous dominant $(25.0 \%)$ and heterozygous groups $(33.3 \%)$, with disease stability in $60 \%$ of cases vs. $25 \%$, respectively $(p=0.01)$. The complete results of the statistical analysis are shown in Table 3.

\section{DISCUSSION}

The primary endpoint of our study was to assess whether SNPs genotype in key genes associated with tumor regression or progression have an impact on patients prognosis in terms of OS and PFS.

In melanoma patients VDR polymorphisms have been largely studied for their role in the development of the disease [61-65], while their influence on prognosis and survival has been evaluated by a limited number of studies.
The prospective study conducted by NewtonBishop et al. [66] considered 872 patients to identify an association between circulating levels of vitamin D and Breslow thickness; in addiction, five SNPs, including Fok1, Bsm1 and Taq1 were genotyped. Except for a weak association between the risk of relapse and the Bsm1 A allele and low circulating levels of vitamin $\mathrm{D}$, no other impact of the SNPs on disease relapse or overall survival was observed. Annika Shäfer et al. [67] evaluated SNPs in VDR gene and other genes involved in vitamin D metabolism in 305 patients with melanoma and 370 healthy volunteers to find a connection between genotype, risk of developing melanoma and its prognosis. No interesting data seemed to arise from this study.

Recently Orlow et al. [46] analyzed the genotype of 38 different SNPs in the VDR gene in 3566 patients to assess their role on melanoma specific-survival. Their results showed that a statistically significant association exists between survival and the SNPs Bsm1 and Taq1 also analyzed in our study. Differently from their results, we showed no influence on OS by aforementioned SNPs presumably due to our small sample and short median time of follow-up (2.6 years compared to 7.6 years of Orlow et al.'s study).

To the best of our knowledge this is the first study which aimed to evaluate the influence of SNPs in the VDR gene on response to antitumor treatment, demonstrating that homozygous recessive patients for 


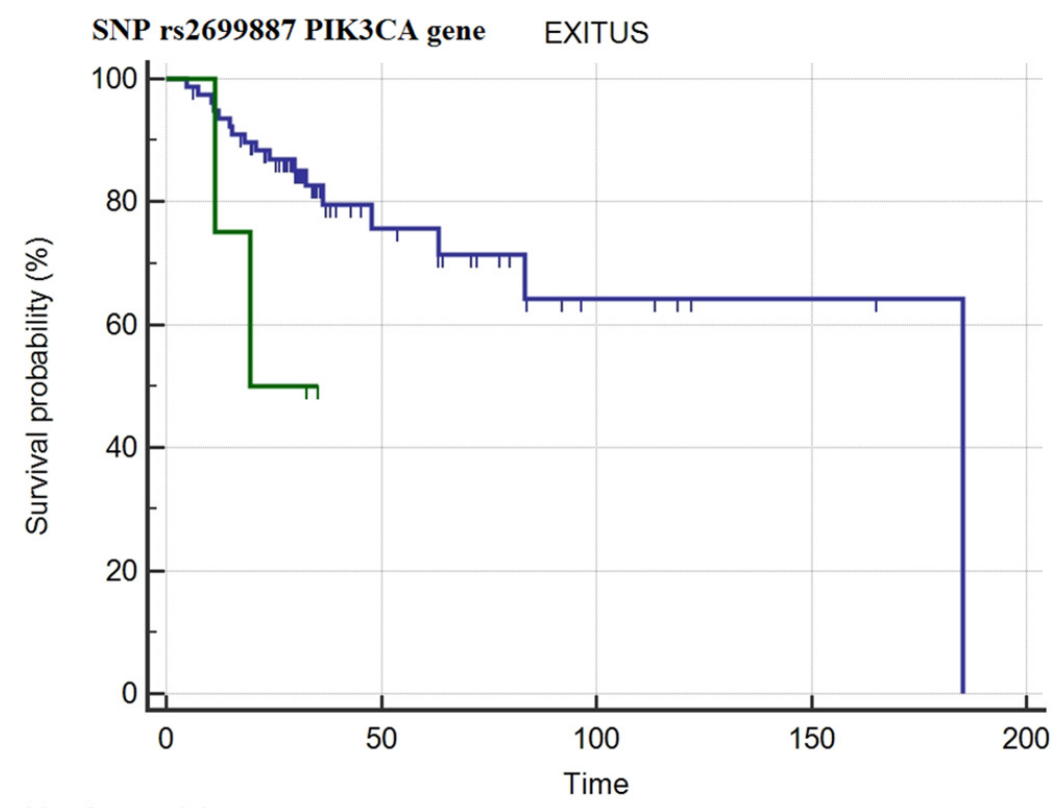

Number at risk

$\begin{array}{ccccc}\text { Group: CC } \\ \mathbf{7 9} \\ \text { Group:TT } \\ 4 & 19 & 5 & 2 & 0 \\ & 0 & 0 & 0 & 0\end{array}$

Figure 1: overall survival curves for SNP rs2699887 of PIK3CA gene in homozygous dominant (genotype CC) and heterozygous (genotype CT) patients (blue curve) and homozygous recessive patients (genotype TT) (green curve).

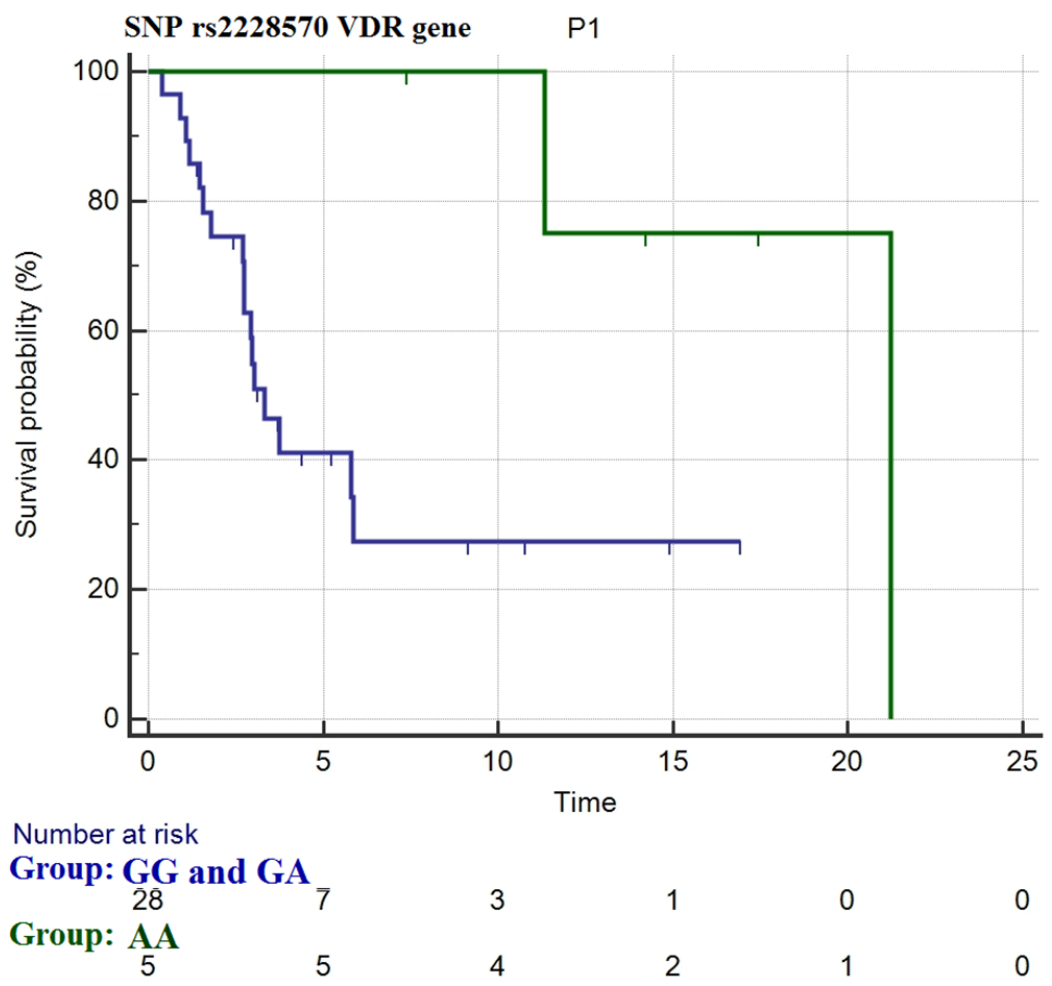

Figure 2: progression free survival for SNP rs2228570 of VDR gene in homozygous dominant (genotype GG) and heterozygous patients (genotype GA) (blue curve) and homozygous recessive patients (genotype AA) (green curve). 
Table 2: summary of first line treatment in BRAF mutated patients

\section{BRAF mutated patients}

\begin{tabular}{ll}
\hline Treatment & $\mathrm{N}(\%)$ \\
Chemotherapy & $1(5.9)$ \\
BRAF +/- MEK inhibitors & $12(70.6)$ \\
ANTI-PD1 & $1(5.9)$ \\
Best supportive care & $3(17.6)$ \\
\hline
\end{tabular}

Table 3: hazard ratios (HR) with $95 \%$ CI and p value of the Mantiel-Haenszel log-rank test for the studied polymorphisms in the different patients groups

\begin{tabular}{|c|c|c|c|c|c|c|}
\hline \multirow{2}{*}{ Gene } & \multirow{2}{*}{ Polymorphism } & \multirow{2}{*}{ Patients'group } & \multicolumn{2}{|c|}{$O S$} & \multicolumn{2}{|l|}{$P F S$} \\
\hline & & & $H R(95 \% C I)$ & Pvalue & $H R$ & Pvalue \\
\hline$P I K 3 C A$ & rs2699887 & $\begin{array}{l}\text { HD and Ht } \\
\text { vs. } \\
\text { HR }\end{array}$ & $0.28(0.02-3.61)$ & 0.0670 & $0.51(0.03-7.94)$ & 0.503 \\
\hline \multirow[t]{2}{*}{ PIK3R1 } & rs3730089 & $\begin{array}{c}\text { HD } \\
\text { vs.Ht }\end{array}$ & $2.11(0.78-5.66)$ & 0.186 & $1.71(0.60-4.84)$ & 0.333 \\
\hline & rs 2228570 & $\begin{array}{l}\text { HD and Ht } \\
\text { vs. } \\
\text { HR }\end{array}$ & $1.27(0.33-4.84)$ & 0.742 & $0.26(0.09-0.69)$ & 0.030 \\
\hline \multirow[t]{2}{*}{$V D R$} & rs 731236 & $\begin{array}{c}\text { HD and Ht } \\
\text { vs. } \\
\text { HR }\end{array}$ & $1.02(0.30-3.48)$ & 0.964 & $1.13(0.39-3.29)$ & 0.812 \\
\hline & rs 1544410 & $\begin{array}{l}\text { HD } \\
\text { vs. } \\
\text { Ht }\end{array}$ & $1.50(0.62-3.62)$ & 0.345 & $1.35(0.55-3.27)$ & 0.478 \\
\hline
\end{tabular}

Fok1 polymorphism have a longer progression free survival and a better disease control rate to the first line of treatment with anti-BRAF +/- anti-MEK drugs when compared to homozygous dominant and heterozygous genotypes.

Nowadays limited data have been published about the SNP rs2699887 in the PIK3CA gene and it has not been investigated in melanoma patients so far.

In particular the aforementioned SNP was studied in esophageal [68], endometrial [28], oral [69], pulmonary [70, 71], and colorectal cancer [72] with various endpoints: risk of tumor development, association with pathological features, risk of metastasis, toxicity to chemotherapy and survival.

Wang et al. [45] studied 115 patients with endometrial cancer observing a better survival for heterozygous genotype in the PIK3CA rs2699887.

In our study we identified a trend $(p=0.06)$ of worse OS in recessive homozygous patients for PIK3CA rs2699887 SNPs vs. dominant and heterozygous ones. This SNPs could become a very interesting prognostic biomarker if it will be confirmed and demonstrated significative in future research.

Few data has been published on the SNP rs3730089 in the PIK3R1 gene, studied only in prostate [73] and colon cancer. Despite no association between the SNP and prostate cancer risk was observed, the homozygous recessive and heterozygous genotypes have been associated with a greater risk of developing colon cancer [74].

Our study is the first to evaluate this SNP rs3730089 in the PIK3R1 gene in melanoma patients and its impact on prognosis, even though no statistical association was found between genotype, OS and PFS.

In conclusion, in our study we showed for the first time that homozygous recessive patients for Fok1 polymorphism have a longer progression free survival and better disease control rate during the first line of treatment with anti-BRAF +/- anti-MEK drugs compared to homozygous dominant and heterozygous genotypes. Furthermore, we first studied SNPs rs3730089 in the PIK3R1 gene and rs2699887 in the PIK3CA gene in 
melanoma patients, observing a trend of worse OS in homozygous recessive patients for the SNP rs2699887 in the PIK3CA gene vs. homozygous dominant and heterozygous genotypes.

The main study limitation is related to the small sample of patients: increasing sample size and time of follow-up would improve the statistical power of our findings allowing us to confirm, most likely, the prognostic and predictive role of the SNPs Fok1 in the VDR gene and rs2699887 in the PIK3CA gene. There are no evidence-based guidelines, up to now, that specify the best therapy sequence for treatment of metastatic melanoma (immunotherapy followed by target treatments or vice versa), therefore it could be interesting to evaluate whether the Fok1 polymorphism is associated with a major efficacy of treatment with BRAF +/- MEK inhibitors regardless of line of therapy.

\section{MATERIALS AND METHODS}

\section{Patients' selection}

We retrospectively reviewed clinical history and follow-up of patients with cutaneous or occult malignant melanoma treated at the Department of Medical Oncology and at the Dermatology Unit of Università Politecnica Marche-Azienda Ospedaliero Universitaria Ospedali Riuniti Umberto I ${ }^{\circ}$-G.M. Lancisi-G. Salesi in Ancona, Italy between 2012 and 2016.

Eligibility criteria included histological diagnosis of malignant melanoma and no contraindications to antitumor therapy. Data was retrospectively collected from patients' medical records.

Recorded patient characteristics and clinicalpathological features included: age, sex, Eastern Cooperative Oncology Group (ECOG) performance status, stage of disease according to the TNM (AJCC 2009) [3], site of tumor, histological features, mutational status of BRAF gene, allele frequencies of the analyzed SNPs and data regarding all the treatments performed by the patients.

For patients who underwent immunotherapy, response to treatment was evaluated with the immune related Response Criteria (irRC) [75].

For all the others, response to therapy was assessed according to RECIST 1.1 (Response Evaluation Criteria In Solid Tumors) [76]. The "Common Terminology Criteria for Adverse Events" (NCI CTCAE, version 4.0) [77] was used to record side effects of anti-tumor therapy.

\section{PI3K and VDR genotyping}

DNA extracted from formalin-fixed paraffinembedded tissue blocks of malignant melanoma or from whole blood was used to PIK3CA, PIK3R1 and VDR genotyping.
Single nucleotide polymorphisms within each gene were selected using the Single Nucleotide Polymorphism database (dbSNP) generated by the National Centre for Biotechnology Information [78] and by reviewing the published literature, using the following criteria:

1. the polymorphism had some degree of likelihood to biologically modify the structure or the expression of the gene.

2. the MAF was above $10 \%$.

3. the genetic polymorphism was well-documented.

On the basis of aforementioned criteria, we selected the following SNPs:

- PIK3CA gene: rs2699887 SNP, located in an intron region in proximity of the 5 '-side, with $\mathrm{C} / \mathrm{T}$ allelic variants.

- PIK3R1 gene: rs3730089 missense SNP, located in exon 6 , with $\mathrm{A} / \mathrm{G}$ allelic variants. In presence of minor allelic variant, PI3K/AKT pathway becomes hyperactivated [79].

- VDR gene: rs2228570 missense SNP, named Fok1, located near starting codon, with $\mathrm{T} / \mathrm{C}$ variants that defined $f$ and $F$ alleles respectively $[80,81]$.

- VDR gene: rs731236 SNP, named Taq1, located in exon 2 , with $\mathrm{C} / \mathrm{T}$ variants that define $\mathrm{t}$ and $\mathrm{T}$ alleles respectively.

- VDR gene: rs1544410 SNP, named Bsm1, located in an intron region, with $\mathrm{A} / \mathrm{G}$ variants [82].

SNP genotyping was performed by TaqMan technology, using SNP genotyping assay. Genotypes were analysed on the 7300 Real-Time PCR System.

\section{Statistical analysis}

The association between categorical variables was evaluated by Fisher exact test for binomial categorical variables and by chi-square test for all other applications. Survival probability was estimated using the KaplanMeier method.

Significant differences in the probability of survival between the strata were evaluated by log-rank test (significance was set at a 0.05 level for all analyses).

For statistical analysis, OS was evaluated from histological diagnosis of melanoma to event or censoring, whereas PFS was considered as the interval between the date of start of 1 st line treatment until death, last follow-up visit or first sign of clinical progression, whichever came first.

Statistical analysis for polymorphisms was conducted considering the outcome of wild type (homozygous dominant) and heterozygous vs. homozygous recessive genotype. 
Nevertheless, in the pooled population, two polymorphisms showed the absence or a poorly representation of homozygous recessive genotype. In these cases for the statistical analysis we confronted wild type with heterozygous patients.

All genetic polymorphisms were examined for deviation from HWE using the Powermarker v.3.25 package [83]. All statistical analyses were performed by using MedCalc Statistical Software version 14.10.2 [84].

\section{Ethic statement}

Ethical committee of our Institution (Comitato Etico Regionale delle Marche, Azienda OspedalieroUniversitaria Ospedali Riuniti Ancona, Via Conca 71, 60126, Ancona, Italy) accepted this study.

All patients accorded their written consent to the research and to all the diagnostic-therapeutic procedures.

\section{ACKNOWLEDGMENTS}

This research did not receive any specific grant from any funding agency in the public, commercial or not-forprofit sector. The study was realized with solely funding from Università Politecnica delle Marche, Ancona Italy.

\section{CONFLICTS OF INTEREST}

All authors disclose no financial and personal relationships with other people or organizations that could inappropriately influence their work.

All authors declare that have not received fees for serving as a speakers or consultants and/or an advisory board members for any organizations. All authors have no received research funding from any organizations. No authors are employees of any organization. No authors own stocks and/or shares in organization. No authors own patent.

All authors declare that they have no competing interests.

All authors contributed to the editorial, read and approved the final manuscript.

Disclose any potential conflicts of interest.

\section{GRANT SUPPORT}

No grants, equipment, drugs, and/or other support facilitated conduct of the work described in the article or the writing of the article itself.

\section{REFERENCES}

1. Siegel RL, Miller KD, Jemal A. Cancer statistics, 2016. CA Cancer J Clin. 2016; 66:7-30.

2. Howlader N, Noone AM, Krapcho M, Garshell J, Neyman N, Altekruse SF, Kosary CL, Yu M, Ruhl J, Tatalovich Z,
Cho H, Mariotto A, Lewis DR, et al. SEER Cancer Statistics Review, 1975-2010, National Cancer Institute. Bethesda, MD, http://seer.cancer.gov/csr/1975_2010/.

3. Balch CM, Gershenwald JE, Soong SJ, Thompson JF, Atkins MB, Byrd DR, Buzaid AC, Cochran AJ, Coit DG, Ding S, Eggermont AM, Flaherty KT, Gimotty PA, et al. Final version of 2009 AJCC Melanoma Staging and Classification. J Clin Oncol. 2009; 27:6199-6206.

4. de Vries E, Nijsten TE, Visser O, Bastiaannet E, van Hattem S, Janssen-Heijnen ML, Coebergh JW. Superior survival of females among 10,538 Dutch melanoma patients is independent of Breslow thickness, histologic type and tumor site. Ann. Oncol. 2008; 19:583-589.

5. Joosse A, Collette S, Suciu S, Nijsten T, Lejeune F, Kleeberg UR, Coebergh JW, Eggermont AM, de Vries E. Superior outcome of women with stage I/II cutaneous melanoma: pooled analysis of four European Organisation for Research and Treatment of Cancer phase III trials. J Clin Oncol. 2012; 30:2240-47.

6. Lasithiotakis K, Leiter U, Meier F, Eigentler T, Metzler G, Moehrle M, Breuninger H, Garbe C. Age and gender are significant independent predictors of survival in primary cutaneous melanoma. Cancer. 2008; 112:1795-1804.

7. Berwick M, Armstrong BK, Ben-Porat L, Fine J, Kricker A, Eberle C, Barnhill R. Sun exposure and mortality from melanoma. J Natl Cancer Inst. 2005; 97:195-199.

8. Davies JR, Jewell R, Affleck P, Anic GM, Randerson-Moor J, Ozola A, Egan KM, Elliott F, García-Casado Z, Hansson J, Harland M, Höiom V, Jian G, et al. Inherited variation in the PARP1 gene and survival from melanoma. Int. J. Cancer. 2014; 135:1625-1633.

9. Fang S, Wang Y, Chun YS, Liu H, Ross MI, Gershenwald JE, Cormier JN, Royal RE, Lucci A, Schacherer CW, Reveille JD, Chen W, Sui D, et al. Association of common genetic polymorphisms with melanoma patient IL-12p40 blood levels, risk, and outcomes. J. Invest. Dermatol. 2015; 135:2266-2272.

10. Li C, Yin M, Wang LE, Amos CI, Zhu D, Lee JE, Gershenwald JE, Grimm EA, Wei Q. Polymorphisms of nucleotide excision repair genes predict melanoma survival. J. Invest. Dermatol. 2013; 133:1813-1821.

11. Liu H, Wei Q, Gershenwald JE, Prieto VG, Lee JE, Duvic M, Grimm EA, Wang LE. Influence of single nucleotide polymorphisms in the MMP1 promoter region on cutaneous melanoma progression. Melanoma Res. 2012; 22:169-175.

12. Park JY, Amankwah EK, Anic GM, Lin HY, Walls B, Park H, Krebs K, Madden M, Maddox K, Marzban S, Fang S, Chen W, Lee JE, et al. Gene variants in angiogenesis and lymphangiogenesis and cutaneous melanoma progression. Cancer Epidemiol. Biomarkers Prev. 2013; 22:827-834.

13. Rendleman J, Vogelsang M, Bapodra A, Adaniel C, Silva I, Moogk D, Martinez CN, Fleming N, Shields J, Shapiro R, Berman R, Pavlick A, Polsky D, et al. Genetic associations of the interleukin locus at 1q32.1 with clinical outcomes of cutaneous melanoma. J Med Genet. 2015; 52:231-239. 
14. Yin J, Liu H, Liu Z, Wang LE, Chen WV, Zhu D, Amos CI, Fang S, Lee JE, Wei Q. Genetic variants in Fanconi anemia pathway genes BRCA2 and FANCA predict melanoma survival. J. Invest. Dermatol. 2015; 135:542-550.

15. Afzal S, Bojesen SE, Nordestgaard BG. Low plasma 25-hydroxyvitamin D and risk of tobacco-related cancer. Clin Chem. 2013; 59:771-80.

16. Arcaro A, Guerreiro AS. The phosphoinositide 3-kinase pathway in human cancer: genetic alterations and therapeutic implications. Curr Genomics. 2007; 8:271-306.

17. Engelman JA, Luo J, Cantley LC. The evolution of phosphatidylinositol 3-kinases as regulators of growth and metabolism. Nat Rev Genet. 2006; 7:606-19.

18. Shayesteh L, Lu Y, Kuo WL, Baldocchi R, Godfrey T, Collins C, Pinkel D, Powell B, Mills GB, Gray JW. PIK3CA is implicated as an oncogene in ovarian cancer. Nat Genet. 1999; 21:99-102.

19. Mei ZB, Duan CY, Li CB, Cui L, Ogino S. Prognostic role of tumor PIK3CA mutation in colorectal cancer: a systematic review and meta-analysis. Ann Oncol. 2016; 27:1836-48.

20. Broderick DK, Di C, Parrett TJ, Samuels YR, Cummins JM, McLendon RE, Fults DW, Velculescu VE, Bigner DD, Yan H. Mutations of PIK3CA in anaplastic oligodendrogliomas, high-grade astrocytomas, and medulloblastomas. Cancer Res. 2004; 64:5048-50.

21. Bachman KE, Argani P, Samuels Y, Silliman N, Ptak J, Szabo S, Konishi H, Karakas B, Blair BG, Lin C, Peters BA, Velculescu VE, Park BH. The PIK3CA gene is mutated with high frequency in human breast cancers. Cancer Biol Ther. 2004; 3:772-5.

22. Harada K, Baba Y, Shigaki H, Ishimoto T, Miyake K, Kosumi K, Tokunaga R, Izumi D, Ohuchi M, Nakamura K, Kiyozumi Y, Kurashige J, Iwatsuki M, et al. Prognostic and clinical impact of PIK3CA mutation in gastric cancer: pyrosequencing technology and literature review. BMC Cancer. 2016; 16:400.

23. Samuels Y, Wang Z, Bardelli A, Silliman N, Ptak J, Szabo S, Yan H, Gazdar A, Powell SM, Riggins GJ, Willson JK, Markowitz S, Kinzler KW, et al. High frequency of mutations of the PIK3CA gene in human cancers. Science. 2004; 304:554.

24. Bader AG, Kang S, Zhao L, Vogt PK. Oncogenic PI3K deregulates transcription and translation. Nat Rev Cancer. 2005; 5:921-9.

25. Kang S, Bader AG, Vogt PK. Phosphatidylinositol 3-kinase mutations identified in human cancer are oncogenic. Proc Natl Acad Sci USA. 2005; 102:802-07.

26. Manca A, Lissia A, Capone M, Ascierto PA, Botti G, Caracò C, Stanganelli I, Colombino M, Sini M, Cossu A, Palmieri G. Activating PIK3CA mutations coexist with BRAF or NRAS mutations in a limited fraction of melanomas. $\mathrm{J}$ Transl Med. 2015; 13:37.
27. Philp AJ, Campbell IG, Leet C, Vincan E, Rockman SP, Whitehead RH, Thomas RJ, Phillips WA. The phosphatidylinositol 3'-kinase p85alpha gene is an oncogene in human ovarian and colon tumors. Cancer Res. 2001; 61:7426-9.

28. Cheung LW, Hennessy BT, Li J, Yu S, Myers AP, Djordjevic B, Lu Y, Stemke-Hale K, Dyer MD, Zhang F, Ju Z, Cantley LC, Scherer SE, et al. High frequency of PIK3R1 and PIK3R2 mutations in endometrial cancer elucidates a novel mechanism for regulation of PTEN protein stability. Cancer Discov. 2011; 1:170-85.

29. Koutros S, Schumacher FR, Hayes RB, Ma J, Huang WY, Albanes D, Canzian F, Chanock SJ, Crawford ED, Diver WR, Feigelson HS, Giovanucci E, Haiman CA, et al. Pooled analysis of phosphatidylinositol 3-kinase pathway variants and risk of prostate cancer. Cancer Res. 2010; 70:2389-96.

30. Hartmann C, Bartels G, Gehlhaar C, Holtkamp N, von Deimling A. PIK3CA mutations in glioblastoma multiforme. Acta Neuropathol. 2005; 109:639-42.

31. Shull AY, Latham-Schwark A, Ramasamy P, Leskoske K, Oroian D, Birtwistle MR, Buckhaults PJ. Novel somatic mutations to PI3K pathway genes in metastatic melanoma. PLoS One. 2012; 7:e43369.

32. Kim SH, Chen G, King AN, Jeon CK, Christensen PJ, Zhao L, Simpson RU, Thomas DG, Giordano TJ, Brenner DE, Hollis B, Beer DG, Ramnath N. Characterization of vitamin $\mathrm{D}$ receptor (VDR) in lung adenocarcinoma. Lung Cancer. 2012; 77:265-71.

33. Srinivasan M, Parwani AV, Hershberger PA, Lenzner DE, Weissfeld JL. Nuclear vitamin D receptor expression is associated with improved survival in non-small cell lung cancer. J. Steroid Biochem. Mol. Biol. 2011; 123:30-36.

34. Berger U, McClelland RA, Wilson P, Greene GL, Haussler MR, Pike JW, Colston K, Easton D, Coombes RC. Immunocytochemical determination of estrogen receptor, progesterone receptor, and 1,25-dihydroxyvitamin D3 receptor in breast cancer and relationship to prognosis. Cancer Res. 1991; 51:239-44.

35. Ditsch N, Toth B, Mayr D, Lenhard M, Gallwas J, Weissenbacher T, Dannecker C, Friese K, Jeschke U. The association between vitamin $\mathrm{D}$ receptor expression and prolonged overall survival in breast cancer. J Histochem Cytochem. 2012; 60:121-9.

36. Brożyna AA, Jozwicki W, Janjetovic Z, Slominski AT. Expression of vitamin D receptor decreases during progression of pigmented skin lesions. Hum Pathol. 2011; 42:618-31.

37. Brożyna AA, Jóźwicki W, Slominski AT. Decreased VDR expression in cutaneous melanomas as marker of tumor progression: new data and analyses. Anticancer Res. 2014; 34:2735-2743.

38. Essa S, Reichrath S, Mahlknecht U, Montenarh M, Vogt T, Reichrath J. Signature of VDR miRNAs and epigenetic 
modulation of vitamin D signaling in melanoma cell lines. Anticancer Res. 2012; 32:383-389.

39. Uitterlinden AG, Fang Y, Van Meurs JB, Pols HA, Van Leeuwen JP. Genetics and biology of vitamin D receptor polymorphisms. Gene. 2004; 338:143-56.

40. Orlow I, Reiner AS, Thomas NE, Roy P, Kanetsky PA, Luo L, Paine S, Armstrong BK, Kricker A, Marrett LD, Rosso S, Zanetti R, Gruber SB, et al, and GEM Study Group. Vitamin D receptor polymorphisms and survival in patients with cutaneous melanoma: a population-based study. Carcinogenesis. 2016; 37:30-38. https://doi.org/10.1093/ carcin/bgv157.

41. Pang B, Sun SP, Gao L, Zhu RL, Zhang LX, An C, Liu ZY, Liu GJ. A single nucleotide polymorphism in PIK3CA gene is inversely associated with $\mathrm{P} 53$ protein expression in breast cancer. Med Oncol. 2014; 31:30.

42. Pande M, Bondy ML, Do KA, Sahin AA, Ying J, Mills GB, Thompson PA, Brewster AM. Association between germline single nucleotide polymorphisms in the PI3K-AKT-mTOR pathway, obesity, and breast cancer disease-free survival. Breast Cancer Res Treat. 2014; 147:381-7.

43. Wang J, Chai YL, Wang T, Liu JH, Dai PG, Liu Z. Genetic alterations of PIK3CA and tumor response in patients with locally advanced cervical squamous cell carcinoma treated with cisplatin-based concurrent chemoradiotherapy. Exp Mol Pathol. 2015; 98:407-10.

44. Guo L, Wu H, Zhu J, Zhang C, Ma J, Lan J, Xie X. Genetic variations in the PI3K/AKT pathway predict platinum-based neoadjuvant chemotherapeutic sensitivity in squamous cervical cancer. Life Sci. 2015; 143:217-24.

45. Wang LE, Ma H, Hale KS, Yin M, Meyer LA, Liu H, Li J, Lu KH, Hennessy BT, Li X, Spitz MR, Wei Q, Mills GB. Roles of genetic variants in the PI3K and RAS/RAF pathways in susceptibility to endometrial cancer and clinical outcomes. J Cancer Res Clin Oncol. 2012; 138:377-85.

46. Zhu J, Wang M, Zhu M, He J, Wang JC, Jin L, Wang XF, Xiang JQ, Wei Q. Associations of PI3KR1 and mTOR polymorphisms with esophageal squamous cell carcinoma risk and gene-environment interactions in Eastern Chinese populations. Sci Rep. 2015; 5:8250.

47. Chen M, Gu J, Delclos GL, Killary AM, Fan Z, Hildebrandt MA, Chamberlain RM, Grossman HB, Dinney CP, Wu X. Genetic variations of the PI3K-AKT-mTOR pathway and clinical outcome in muscle invasive and metastatic bladder cancer patients. Carcinogenesis. 2010; 31:1387-91.

48. Lundin AC, Söderkvist P, Eriksson B, BergmanJungeström M, Wingren S, and South-East Sweden Breast Cancer Group. Association of breast cancer progression with a vitamin D receptor gene polymorphism. Cancer Res. 1999; 59:2332-34. https://www.ncbi.nlm.nih.gov/ pubmed/10344739.

49. Heist RS, Zhou W, Wang Z, Liu G, Neuberg D, Su L, Asomaning K, Hollis BW, Lynch TJ, Wain JC, Giovannucci E, Christiani DC. Circulating 25-hydroxyvitamin D, VDR polymorphisms, and survival in advanced non-small-cell lung cancer. J Clin Oncol. 2008; 26:5596-602.

50. Zhou W, Heist RS, Liu G, Neuberg DS, Asomaning K, $\mathrm{Su}$ L, Wain JC, Lynch TJ, Giovannucci E, Christiani DC. Polymorphisms of vitamin D receptor and survival in earlystage non-small cell lung cancer patients. Cancer Epidemiol Biomarkers Prev. 2006; 15:2239-45.

51. Tamez S, Norizoe C, Ochiai K, Takahashi D, Shimojima A, Tsutsumi Y, Yanaihara N, Tanaka T, Okamoto A, Urashima M. Vitamin D receptor polymorphisms and prognosis of patients with epithelial ovarian cancer. Br. J. Cancer. 2009; 101:1957-196.

52. Zgaga L, Theodoratou E, Farrington SM, Din FV, Ooi LY, Glodzik D, Johnston S, Tenesa A, Campbell H, Dunlop MG. Plasma vitamin D concentration influences survival outcome after a diagnosis of colorectal cancer. J Clin Oncol. 2014; 32:2430-9.

53. Speer G, Dworak O, Cseh K, Bori Z, Salamon D, Török I, Winkler G, Vargha P, Nagy Z, Takács I, Kucsera M, Lakatos P. Vitamin D receptor gene BsmI polymorphism correlates with erbB-2/HER-2 expression in human rectal cancer. Oncology. 2000; 58:242-7.

54. Obara W, Suzuki Y, Kato K, Tanji S, Konda R, Fujioka T. Vitamin D receptor gene polymorphisms are associated with increased risk and progression of renal cell carcinoma in a Japanese population. Int. J. Urol. 2007; 14:483-487.

55. Holt SK, Kwon EM, Koopmeiners JS, Lin DW, Feng Z, Ostrander EA, Peters U, Stanford JL. Vitamin D pathway gene variants and prostate cancer prognosis. Prostate. 2010; 70:1448-60.

56. Shui IM, Mucci LA, Kraft P, Tamimi RM, Lindstrom S, Penney KL, Nimptsch K, Hollis BW, Dupre N, Platz EA, Stampfer MJ, Giovannucci E. Vitamin D-related genetic variation, plasma vitamin $\mathrm{D}$, and risk of lethal prostate cancer: a prospective nested case-control study. J Natl Cancer Inst. 2012; 104:690-9.

57. Xu Y, Shibata A, McNeal JE, Stamey TA, Feldman D, Peehl DM. Vitamin D receptor start codon polymorphism (FokI) and prostate cancer progression. Cancer Epidemiol Biomarkers Prev. 2003; 12:23-7.

58. Hama T, Norizoe C, Suga H, Mimura T, Kato T, Moriyama H, Urashima M. Prognostic significance of vitamin D receptor polymorphisms in head and neck squamous cell carcinoma. PLoS One. 2011; 6:e29634.

59. Zeljic K, Supic G, Stamenkovic Radak M, Jovic N, Kozomara R, Magic Z. Vitamin D receptor, CYP27B1 and CYP24A1 genes polymorphisms association with oral cancer risk and survival. J Oral Pathol Med. 2012; 41:779-87.

60. Anic GM, Thompson RC, Nabors LB, Olson JJ, Browning JE, Madden MH, Murtagh FR, Forsyth PA, Egan KM. An exploratory analysis of common genetic variants in the vitamin D pathway including genome-wide associated 
variants in relation to glioma risk and outcome. Cancer Causes Control. 2012; 23:1443-9.

61. Gandini S, Raimondi S, Gnagnarella P, Doré JF, Maisonneuve P, Testori A. Vitamin D and skin cancer: a meta-analysis. Eur J Cancer. 2009; 45:634-41.

62. Zhao XZ, Yang BH, Yu GH, Liu SZ, Yuan ZY. Polymorphisms in the vitamin D receptor (VDR) genes and skin cancer risk in European population: a meta-analysis. Arch Dermatol Res. 2014; 306:545-53.

63. Hou W, Wan X, Fan J. Variants Fok1 and Bsm1 on VDR are associated with the melanoma risk: evidence from the published epidemiological studies. BMC Genet. 2015; 16:14.

64. Lee YH, Gyu Song G. Vitamin D receptor FokI, BsmI, TaqI, ApaI, and EcoRV polymorphisms and susceptibility to melanoma: a meta-analysis. J BUON. 2015; 20:235-43.

65. Mocellin S, Nitti D. Vitamin D receptor polymorphisms and the risk of cutaneous melanoma: a systematic review and meta-analysis. Cancer. 2008; 113:2398-407.

66. Newton-Bishop JA, Beswick S, Randerson-Moor J, Chang YM, Affleck P, Elliott F, Chan M, Leake S, Karpavicius B, Haynes S, Kukalizch K, Whitaker L, Jackson S, et al. Serum 25-hydroxyvitamin D3 levels are associated with breslow thickness at presentation and survival from melanoma. J Clin Oncol. 2009; 27:5439-44.

67. Schäfer A, Emmert S, Kruppa J, Schubert S, Tzvetkov M, Mössner R, Reich K, Berking C, Volkenandt M, Pföhler C, Schön MP, Vogt T, König IR, et al. No association of vitamin $\mathrm{D}$ metabolism-related polymorphisms and melanoma risk as well as melanoma prognosis: a casecontrol study. Arch Dermatol Res. 2012; 305:353-61.

68. Hildebrandt MA, Yang H, Hung MC, Izzo JG, Huang M, Lin J, Ajani JA, Wu X. Genetic variations in the PI3K/ $\mathrm{PTEN} / \mathrm{AKT} / \mathrm{mTOR}$ pathway are associated with clinical outcomes in esophageal cancer patients treated with chemoradiotherapy. J Clin Oncol. 2009; 27:857-71.

69. Wan X, Li X, Yang J, Lv W, Wang Q, Chen Y, Li Y. Genetic association between PIK3CA gene and oral squamous cell carcinoma: a case control study conducted in Chongqing, China. Int J Clin Exp Pathol. 2015; 8:13360-6.

70. Wang C, Nie H, Li Y, Liu G, Wang X, Xing S, Zhang L, Chen X, Chen Y, Li Y. The study of the relation of DNA repair pathway genes SNPs and the sensitivity to radiotherapy and chemotherapy of NSCLC. Sci Rep. 2016; 6:26526.

71. Pu X, Hildebrandt MA, Lu C, Lin J, Stewart DJ, Ye Y, Gu J, Spitz MR, Wu X. PI3K/PTEN/AKT/mTOR pathway genetic variation predicts toxicity and distant progression in lung cancer patients receiving platinum-based chemotherapy. Lung Cancer. 2011; 71:82-8.

72. Lin L, Zhang Z, Zhang W, Wang L, Wang J. Roles of genetic variants in the PI3K/PTEN pathways in susceptibility to colorectal carcinoma and clinical outcomes treated with FOLFOX regimen. Int J Clin Exp Pathol. 2015; 8:13314-22.

73. Paradis AE, Kantoff PW, Giovannucci E, Stampfer MJ, Ma J. Association between the Met326Ile polymorphism of the p85alpha regulatory subunit of phosphatidylinositol 3-kinase and prostate cancer risk: a prospective study. Cancer Epidemiol Biomarkers Prev. 2003; 12:172-3.

74. Li L, Plummer SJ, Thompson CL, Tucker TC, Casey G. Association between phosphatidylinositol 3-kinase regulatory subunit p85alpha Met326Ile genetic polymorphism and colon cancer risk. Clin Cancer Res. 2008; 14:633-7.

75. Wolchok JD, Hoos A, O'Day S, Weber JS, Hamid O, Lebbé C, Maio M, Binder M, Bohnsack O, Nichol G, Humphrey R, Hodi FS. Guidelines for the evaluation of immune therapy activity in solid tumors: immune-related response criteria. Clin Cancer Res. 2009; 15:7412-20.

76. Eisenhauer EA, Therasse P, Bogaerts J, Schwartz LH, Sargent D, Ford R, Dancey J, Arbuck S, Gwyther S, Mooney M, Rubinstein L, Shankar L, Dodd L, et al. New response evaluation criteria in solid tumours: revised RECIST guideline (version 1.1). Eur J Cancer. 2009; 45:228-47.

77. http://evs.nci.nih.gov/ftp1/CTCAE/CTCAE_4.03_2010-0614_QuickReference_5x7.pdf).

78. http://www.ncbi.nlm.nih.gov/SNP) (National Centre for Biotechnology Information (NCBI) CIPF Single Nucleotide Polymorphism database. http://www.ncbi.nlm.nih.gov/SNP)

79. Luo J, Cantley LC. The negative regulation of phosphoinositide 3-kinase signaling by p85 and its implication in cancer. Cell Cycle. 2005; 4:1309-12.

80. Jurutka PW, Remus LS, Whitfield GK, Thompson PD, Hsieh JC, Zitzer H, Tavakkoli P, Galligan MA, Dang HT, Haussler CA, Haussler MR. The polymorphic N terminus in human vitamin $\mathrm{D}$ receptor isoforms influences transcriptional activity by modulating interaction with transcription factor IIB. Mol Endocrinol. 2000; 14:401-20.

81. Whitfield GK, Remus LS, Jurutka PW, et al. Are human vitamin D receptor polymorphisms functionally significant? In: Norman AW, Bouillon R, Thomasset M, editors. Vitamin D Endocrine System, Structural, Biological, Genetic and Clinical Aspects. Riverside (CA): University of California; 2000. pp. 817-23.

82. Köstner K, Denzer N, Müller CS, Klein R, Tilgen W, Reichrath J. The relevance of vitamin D receptor (VDR) gene polymorphisms for cancer: a review of the literature. Anticancer Res. 2009; 29:3511-36.

83. www.statgen.ncsu.edu/powermarker.

84. MedCalc Software bvba, Ostend, Belgium; https://www. medcalc.org/. 